\title{
CHALCOPYRITE LEACHING IN ACID MEDIA: A REVIEW
}

\author{
Grozdanka D. Bogdanović ${ }^{1 *}$, Sanja Petrović ${ }^{2}$, Miroslav Sokić3, \\ Milan M. Antonijevic ${ }^{1}$ \\ ${ }^{1}$ University of Belgrade, Technical Faculty in Bor, VJ 12, P.O. Box 50, 19210 Bor, \\ Serbia \\ ${ }^{2}$ Mining and Metallurgy Institute Bor, Zeleni Bulevar 35, 19210 Bor, Serbia; \\ ${ }^{3}$ Institute for Technology of Nuclear and Other Mineral Raw Materials, \\ Bulevar Franš D'eperea 86, 11000 Belgrade, Serbia
}

Received 29.06.2020

Accepted 15.07.2020

\begin{abstract}
In the modern practice of copper production, more attention is increasingly being given to the possibility of treating low-percentage sulphide ores that cannot be treated with conventional procedures (crushing, grinding, flotation). In addition, the processes of obtaining copper from complex sulphide concentrates, which cannot undergo pyrometallurgical processing, are increasingly being investigated. In most cases, the extraction of copper from such raw materials is achieved by applying the leaching procedures.

Since chalcopyrite $\left(\mathrm{CuFeS}_{2}\right)$ is the most abundant copper sulphide mineral, a great part of the research is focused on studying the behaviour of chalcopyrite in the leaching process, because processes of copper extraction from increasingly poor raw materials may be created using results of these studies. In addition, the main goal of these researches is to investigate the kinetics and mechanism of oxidation of chalcopyrite under the influence of various oxidants $\left(\mathrm{O}_{2}, \mathrm{Fe}^{3+}, \mathrm{H}_{2} \mathrm{O}_{2}\right.$, chlorate ions, etc.) and in the same time obtaining data necessary for the development of copper production process that could satisfy increasingly technological, economic and environmental stringent criteria.

This paper presents the existing knowledge of chalcopyrite leaching and phenomena that follow chalcopyrite oxidation in acidic sulphate and chloride solutions.
\end{abstract}

Keywords: chalcopyrite; leaching; dissolution; oxidation mechanism.

*Corresponding author: Grozdanka D. Bogdanović, gbogdanovic@tfbor.bg.ac.rs 


\section{Contents}

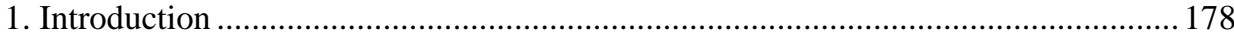

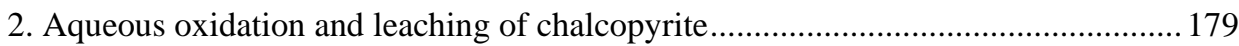

2.1. Formation of a passive layer on the chalcopyrite surface ................................ 179

2.2. Leaching of chalcopyrite in sulphate solutions............................................. 181

2.2.1. Sulphuric acid - Fe (III) ions ..................................................... 181

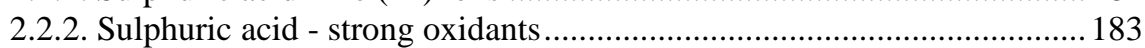

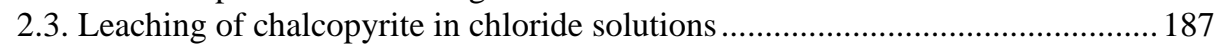

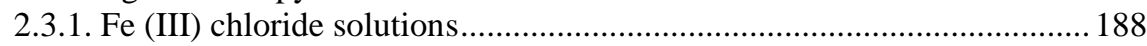

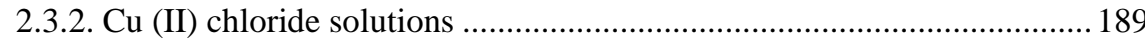

\section{Introduction}

Chalcopyrite is one of the most important and most abundant copper sulphide minerals [1-3]. It often occurs with other minerals in ore deposits, such as pyrite $\left(\mathrm{Fe} \mathrm{S}_{2}\right)$, galena $(\mathrm{PbS})$ and sphalerite $(\mathrm{ZnS})$. These minerals are mainly separated by flotation [4-6] and treated with common pyrometallurgical processes. Today, about $80-85 \%$ of the copper produced in the world is obtained by classical pyrometallurgical processes that are applied to relatively rich and less complex ores and concentrates [7].

Industrial processes related to the hydrometallurgical treatment of sulphide minerals, which include processes and operations in aqueous solutions, will be significantly more represented in the future due to the possibility of processing the increasingly poor primary raw materials [8-11] and complex sulphide concentrates [12-14]. The emission of harmful gases into the atmosphere does not accompany these processes.

The existing commercial heap leaching processes are applied to raw materials in which primary minerals are partially converted to secondary sulphide and oxide minerals. Although a great number of processes for obtaining copper from chalcopyrite ores have been studied and developed, they have yet to be successfully applied to chalcopyrite on an industrial scale $[2,10,15,16]$. The slow leaching reaction of chalcopyrite is one of the main and limiting factors in copper production in industrial conditions [16, 17].

Unlike many other copper minerals, chalcopyrite is very inert to chemical and microbiological oxidation due to its special crystal and electronic structure [18-20]. Chalcopyrite has a crystal structure in which iron and copper ions are in tetrahedral coordination with sulphur [21]. The bond in chalcopyrite is covalent with atomic fluctuations between the two ionic conditions $\mathrm{Cu}^{+} \mathrm{Fe}^{3+} \mathrm{S}_{2}{ }^{2-}$ and $\mathrm{Cu}^{2+} \mathrm{Fe}^{2+} \mathrm{S}_{2}{ }^{2-}$ [22]. The reason for its refractory nature is the formation of a solid passive layer on its surface, which limits the contact of the mineral with the leaching agent and the diffusion process $[23,24]$ and leads to decreasing metal extraction. For this reason, finding new ways to improve the dissolution rate and the more efficient extraction of metals from chalcopyrite is still a topical issue.

Iron (III) and copper (II) ions are used as oxidants for chalcopyrite leaching in sulphate and chloride media. Many studies have shown that this mineral is very unreactive at atmospheric leaching conditions, and at moderate temperatures, around $60^{\circ} \mathrm{C}[1,7,16$, 25-29]. However, the corrosive nature of iron (III) chloride and the slow leaching reaction 
of chalcopyrite with iron (III) sulphate have also influenced research to focus on the use of other oxidizing agents in the leaching process. In addition to the above-mentioned oxidants, research has been done, and other oxidizing agents have been used, such as hydrogen peroxide [30-33], dichromate ions [34], chlorate ions [35], silver ions [36, 37], ozone [38], nitrate ions [39, 40]. The application of microwaves [41, 42], mechanical and chemical activation [43] and organic compounds [44, 45], and the use of silver ions have also been studied in order to develop the technological processes for obtaining copper that could satisfy increasingly stringent technological, economic and environmental criteria. These studies, which are part of numerous references on the behaviour of chalcopyrite in acidic solutions, have shown that there is extensive knowledge of chalcopyrite leaching reactions. However, many ambiguities have been revealed in the behaviour of chalcopyrite, which requires that this issue has to be further studied.

This paper aims to present the results of the chemical leaching of chalcopyrite in acid sulphate and chloride media in the presence of various oxidants. Here is a brief overview of the mechanism and kinetics of chalcopyrite dissolution in different media, types of reaction products, and achieved extractions of metals under different oxidation conditions (concentration of leaching agent and oxidant concentration, temperature, agitation, the redox potential of the solution), etc.

\section{Aqueous oxidation and leaching of chalcopyrite}

\subsection{Formation of a passive layer on the chalcopyrite surface}

The slow leaching reaction of chalcopyrite is one of the main and limiting factors for obtaining copper from this mineral in the hydrometallurgical process. Most authors agree that the slow leaching kinetics of chalcopyrite is a consequence of the formation of reaction products on the mineral's surface [3, 7, 46-48]. The layers of reaction products can act as a barrier for further dissolution, i.e. they contribute to the formation of surface passivation. The nature of these layers is still the subject of numerous research and discussions, based on which different interpretations occur [24].

The nature of the passive layer and the mechanism of its formation have not been completely explained. However, it is usually assumed that elemental sulphur, metaldeficient sulphides, polysulphides, iron compounds, or jarosite, create a passive layer on the chalcopyrite surface [24, 49-58]. The differences between certain hypotheses, regarding the nature and composition of reaction products on the surface of chalcopyrite, partly occur due to different proposed kinetic expressions for explaining changes in leaching products caused by the application of different oxidants. On the other hand, different stages occur in the oxidative leaching process that are difficult to be distinguished. For this reason, the products formed at the end of the leaching process are proposed as those responsible for passivity, and spectroscopic techniques determine them.

Some researchers claim that the formation of elemental sulphur on the surface of $\mathrm{CuFeS}_{2}$ slows down the dissolution of this mineral [51]. Parker et al. [52] rejected the assumption that the sulphur layer is the cause of the slow dissolution rate of chalcopyrite and suggested that metal deficient polysulphide with semiconductor properties leads to a decrease in the dissolution rate. Klauber et al. [49] investigated types of sulphur formed on $\mathrm{CuFeS}_{2}$ surface during chemical leaching in an acidic medium using $\mathrm{X}$-ray photoelectron spectroscopy. The results showed that sulphur is the main surface product that occurs during acid leaching with iron (III) ions. Another relevant leaching product 
on $\mathrm{CuFeS}_{2}$ surface is disulphide ion $\mathrm{S}_{2}{ }^{2-}$. However, Parker et al. [59] claims that only the following forms of sulphur were detected on the surface of the leached chalcopyrite: $\mathrm{S}^{2-}$, $\mathrm{S}_{2}{ }^{2-}, \mathrm{S}^{\circ}$, and $\mathrm{SO}_{4}{ }^{2-}$.

Harmer et al. [54] used X-ray photoelectron spectroscopy (XPS), secondary ion mass spectrometry (TOF-SIMS), and scanning electron microscopy (SEM) to identify the presence of passivating layers formed during leaching of chalcopyrite in perchloric acid. These authors proposed that the formation of passivation layers during chalcopyrite leaching takes place in three stages. The first stage of oxidation involves the release of copper and iron ions into solution and polymerization of monosulphide $\mathrm{S}^{2-}$ to polysulphide $\mathrm{S}_{\mathrm{n}}{ }^{2-}$. In the next reduction step, there is no release of cations into the solution, but there is a change in the surface of the chalcopyrite. It has been observed that $\mathrm{S}_{\mathrm{n}}{ }^{2-}$ polysulphide, as well as other short-chain polysulphides, are reduced to the formation of elemental sulphur. The further release of the cations follows the final stage of oxidation.

Hackl et al. [58] found that elemental sulphur is sufficiently porous and not limit the diffusion of reactants/reaction products. The passive layer consists of copper sulphide.

In electrochemical studies of chalcopyrite dissolution in a mixed chloride-sulphate medium, it was found that surface passivation does not occur due to the formation of an elemental sulphur layer. It was determined that passivation layers consist of metaldeficient polysulphides $\left(\mathrm{Cu}_{1-\mathrm{x}} \mathrm{Fe}_{1-\mathrm{y}} \mathrm{S}_{2-\mathrm{z}}\right)$ [50, 57]. In previous studies, Jones and Peters [60] identified covellite ( $\mathrm{CuS})$ as an intermediate product in the anodic dissolution of chalcopyrite. Later, McMillan et al. [61] noticed the formation of a product layer containing covellite and elemental sulphur during the anodic dissolution of chalcopyrite in chloride media. Parker et al. [52] noticed the formation of blue covellite on chalcopyrite surface that is anodically oxidized at a potential of $0.4 \mathrm{~V}$ in acid chloride solutions. The authors assumed that $\mathrm{CuS}$ could be a product of the reaction of $\mathrm{CuCl}_{2}{ }^{-}$ion with sulphur or a product of the reduction process involving the formation of $\mathrm{H}_{2} \mathrm{~S}$ in acidic $\mathrm{HCl}$ solutions. In electrochemical studies of chalcopyrite oxidation, Yin et al. [62] determined that the nature of the passive layer depends on $\mathrm{pH}$ value and potential. In strongly acidic solutions, a passive layer consisting of $\mathrm{CuS}_{2}$ (at lower potentials) or elemental sulphur (at higher potentials) is formed on the chalcopyrite surface.

Extensive studies have been conducted on the chemistry of jarosite, where the formation and deposition of jarosite on chalcopyrite surface are associated with the long leaching time [51]. Stott et al. [63] assumed that the precipitation of jarosite, on the mineral surface during leaching, leads to a decrease in the dissolution rate. They assumed that the precipitation of Fe (III) ions in the form of iron (III) hydroxide could completely cover the chalcopyrite surface and prevent further dissolution. Parker et al. [59] used Xray photoelectron spectroscopy to analyze the surface reaction intermediates and products of oxidative chalcopyrite leaching in solutions of iron (II) and iron (III) sulphate and confirmed the formation of jarosite.

Cordoba et al. (2008) associate jarosite precipitation with the passive behavior of chalcopyrite [1]. The formation of jarosite also depends on the temperature, $\mathrm{pH}$, and potential of the solution. The mechanism of jarosite formation during leaching may be presented with the following equation (1) [55]:

$3 \mathrm{Fe}_{2}\left(\mathrm{SO}_{4}\right)_{3}+\left(\mathrm{K}, \mathrm{Na}, \mathrm{H}_{3} \mathrm{O}\right)_{2} \mathrm{SO}_{4}+12 \mathrm{H}_{2} \mathrm{O} \rightarrow 2\left(\mathrm{~K}, \mathrm{Na}, \mathrm{H}_{3} \mathrm{O}\right) \mathrm{Fe}_{3}\left(\mathrm{SO}_{4}\right)_{2}(\mathrm{OH})_{6} \downarrow+6 \mathrm{H}_{2} \mathrm{SO}_{4}$ 
The rate of jarosite formation increases with the increase in temperature, whereas the rate is slower at temperatures below $60^{\circ} \mathrm{C}$. The $\mathrm{pH}$ ranges from 1 to 3 , in which jarosite is mostly formed, is "ideal" for bioleaching regarding microorganism activity.

\subsection{Leaching of chalcopyrite in sulphate solutions}

The leaching of chalcopyrite was mostly studied in the sulphate media due to the simplicity and cost of the process. However, the problem that is mainly emphasized in the largest number of papers that studied chalcopyrite oxidation refers to the slower chalcopyrite dissolution rate under atmospheric leaching conditions, resulting in inefficient copper extraction $[1,7,16,29]$. It can be said that the chalcopyrite dissolution rate in an acidic environment depends on a large number of parameters, including the concentration and type of oxidants, agitation rate, particle size, temperature, and acid concentration.

Chalcopyrite dissolves faster in the presence of oxidants. Oxidative leaching of chalcopyrite in the sulphate medium may take place under the influence of the so-called natural oxidants $\left(\mathrm{O}_{2}, \mathrm{Fe}^{3+}\right.$, bacteria) and may be performed under pressure. The chemistry of chalcopyrite dissolution in the sulphuric acid/oxygen system may be represented with the following reactions (2 and 3) [53]:

$$
\begin{aligned}
& \mathrm{CuFeS}_{2}+4 \mathrm{H}^{+}+\mathrm{O}_{2} \rightarrow \mathrm{Cu}^{2+}+\mathrm{Fe}^{2+}+2 \mathrm{~S}^{0}+2 \mathrm{H}_{2} \mathrm{O} \\
& 4 \mathrm{Fe}^{2+}+4 \mathrm{H}^{+}+\mathrm{O}_{2} \rightarrow 4 \mathrm{Fe}^{3+}+2 \mathrm{H}_{2} \mathrm{O}
\end{aligned}
$$

\subsubsection{Sulphuric acid - Fe (III) ions}

The leaching of chalcopyrite in sulphuric acid solution was most studied with $\mathrm{Fe}$ (III) ions as an oxidant. The mechanism of chalcopyrite dissolution in the presence of $\mathrm{Fe}$ (III) ions is represented with the following reactions (4 and 5):

$$
\begin{aligned}
& \mathrm{CuFeS}_{2}+4 \mathrm{Fe}^{3+} \rightarrow \mathrm{Cu}^{2+}+5 \mathrm{Fe}^{2+}+2 \mathrm{~S}^{0} \\
& \mathrm{CuFeS}_{2}+16 \mathrm{Fe}^{3+}+8 \mathrm{H}_{2} \mathrm{O} \rightarrow \mathrm{Cu}^{2+}+17 \mathrm{Fe}^{2+}+2 \mathrm{SO}_{4}^{2-}+16 \mathrm{H}^{+}
\end{aligned}
$$

In reactions (4) and (5), sulphide sulphur is oxidized to elemental sulphur and sulphate, respectively. The reaction is initially fast and gradually slows down [49]. The reaction rate depends on the temperature and specific surface area of particles, provided that agitation is sufficient and that the $\mathrm{pH}$ value of the medium is such that it does not allow the hydrolysis and/or oxidation of iron ions [25].

Dutrizac [51] found that in solution of iron (III) sulphate, the leaching of chalcopyrite is incomplete and slow, and over $90 \%$ of oxidized sulphide sulphur is in the elemental form Author leached chalcopyrite (size class $-14+10 \mu \mathrm{m}$ ) in $\mathrm{Fe}_{2}\left(\mathrm{SO}_{4}\right)_{3}$ solution at $90^{\circ} \mathrm{C}$ and found that a time of 50 hours was required for reaching $90 \%$ of copper extraction. A layer of sulphur was detected on mineral particles, which increased with time and caused stronger passivation of chalcopyrite. Butinelli et al. [64] noticed that chalcopyrite still leaks slowly, even if elemental sulphur is removed during the leaching process with an organic solvent.

Reaction mechanisms of oxidation of chalcopyrite in iron (III) sulphate solution are still the subject of numerous studies, and different interpretations of kinetic data may 
be found in literature $[21,24,29,65]$. The concentration of iron (III) ions was found to affect the chalcopyrite dissolution rate, whereas oxidants have more effect on the lower concentrations of iron ions [1]. Iron (III) ions have a negligible effect on higher concentrations. Hirato et al. [66] found that chalcopyrite dissolution improved when iron (III) sulphate concentrations increased from 0.001 to $0.1 \mathrm{M}$. These authors found that concentrations of $\mathrm{Fe}^{3+}$ and $\mathrm{FeHSO}_{4}{ }^{2+}$ ions increase when total iron concentrations increase, up to the $0.1 \mathrm{M}$. Above this concentration, iron appears in the form of $\mathrm{FeSO}_{4}{ }^{+}$. The authors concluded that the presence of $\mathrm{Fe}^{3+}$ and $\mathrm{FeHSO}_{4}{ }^{2+}$ ions is important for the dissolution of chalcopyrite in the sulphate media.

Howard and Crundwell [67] determined that the chalcopyrite dissolution rate in sulphate solution increases with increasing Fe (III) ion concentration from 0.001 to 0.05 M. Further increase in Fe (III) concentration up to $0.5 \mathrm{M}$ leads to a decrease in the leaching rate. Kaplun et al. [68] and Li et al. [69] found that Fe (III) concentration of 4 $8 \mathrm{mmol} / \mathrm{dm}^{3}$ in the sulphuric acid solution leads to an increase in dissolution rate of chalcopyrite at the initial oxidation stage and that further dissolution results in a decrease of oxidation rate.

Bogdanović et al. [70] studied the leaching of chalcopyrite ore from the Bor deposit and found that the concentration of iron (III) (1 g/dm to $20 \mathrm{~g} / \mathrm{dm}^{3}$ of iron (III) ions) does not affect the chalcopyrite leaching rate, whereas there is sufficient amount of iron ions in the leaching process, which builds up in the process of decomposition of iron oxide minerals by acid. This finding is very important because it indicates that the hydrometallurgical treatment of ore from the Bor deposit does not require adding a new source of iron ions.

The chalcopyrite dissolution rate is also affected by the $\mathrm{pH}$ of the solution, whereas the acid prevents the hydrolysis reaction and precipitation of iron (III) salts. However, chalcopyrite was found to dissolve poorly at low $\mathrm{pH}$ values $(\mathrm{pH}<1.0)$, and that a layer of iron-deficient chalcopyrite is created on the mineral surface, which results in chalcopyrite passivation [27]. At higher $\mathrm{pH}$ values, chalcopyrite is more easily oxidized by oxygen/iron (III) present in leaching solutions. Cordoba et al. [1] found that with a decrease in $\mathrm{pH}$ value of the solution, the chalcopyrite dissolution rate decreases, and chalcopyrite is not oxidized by iron (III) ions under these conditions, rather by $\mathrm{FeSO}_{4}{ }_{-}^{-}$ ions.

Iron (II) ions are created as a reaction product in the process of chalcopyrite leaching with $\mathrm{Fe}_{2}\left(\mathrm{SO}_{4}\right)_{3}-\mathrm{H}_{2} \mathrm{SO}_{4}$. Therefore, it is necessary to know the influence of $\mathrm{FeSO}_{4}$ on the chalcopyrite leaching rate. Most of the studies have shown that iron (II) ions affect the leaching of chalcopyrite only as a source of iron (III) ions and that their concentration should be reduced as much as possible to increase the leaching rate. However, Hiroyshi et al. $[36,71,72]$ report that $\mathrm{FeSO}_{4}$ extracts copper more efficiently than $\mathrm{Fe}_{2}\left(\mathrm{SO}_{4}\right)_{3}$. These authors showed that the oxidation of chalcopyrite with dissolved oxygen and/or iron (III) ions might be accelerated with high concentrations of iron (II) ions in sulphuric acid solutions and in the presence of high concentrations of copper (II) ions [36, 75, 76]. Based on this, the authors proposed a reaction model according to which the oxidation of chalcopyrite takes place in two reaction stages:

- Stage I represents a reduction of chalcopyrite to chalcocite $\left(\mathrm{Cu}_{2} \mathrm{~S}\right)$ in the presence of $\mathrm{Fe}(\mathrm{II})$ and $\mathrm{Cu}(\mathrm{II})$ ions (reaction 6):

$\mathrm{CuFeS}_{2}+3 \mathrm{Cu}^{2+}+3 \mathrm{Fe}^{2+}=2 \mathrm{Cu}_{2} \mathrm{~S}+4 \mathrm{Fe}^{3+}$ 
- $\quad$ Stage II involves oxidation of chalcocite $\left(\mathrm{Cu}_{2} \mathrm{~S}\right)$ to $\mathrm{Cu}$ (II) ions and elemental sulphur with dissolved oxygen and/or Fe (III) ions (reactions 7 and 8):

$\mathrm{Cu}_{2} \mathrm{~S}+4 \mathrm{H}^{+}+\mathrm{O}_{2}=2 \mathrm{Cu}^{2+}+\mathrm{S}^{0}+2 \mathrm{H}_{2} \mathrm{O}$

$\mathrm{Cu}_{2} \mathrm{~S}+4 \mathrm{Fe} e^{3+}=2 \mathrm{Cu}^{2+}+\mathrm{S}^{0}+4 \mathrm{Fe} e^{2+}$

Based on the presented model, the authors explain that the redox potential of the solution controls the extraction of copper, and it is a function of the concentration of $\mathrm{Cu}$ (II) and Fe (II) ions in the solution.

2.2.2. Sulphuric acid - strong oxidants

The presented results of chalcopyrite leaching in sulphate solutions using Fe (III) ions and/or dissolved oxygen as oxidants indicate that the obtained extraction values are not high, especially if oxidation takes place under the atmospheric leaching conditions. Therefore, chalcopyrite oxidation was performed using stronger oxidizing agents, which, due to higher oxidation potentials, can more effectively influence the kinetics of the dissolution process. For this purpose, the following oxidizing agents were examined: hydrogen peroxide [30-33], ozone [38], dichromate ions [34], chlorate ions [35], persulphate ion [73], etc.

\subsubsection{Sulphuric acid -hydrogen peroxide}

The high oxidation-reduction potential of peroxide (1.77 V, SHE) made this reagent widely used in the oxidation of almost all sulphide minerals. The dissolution of chalcopyrite with hydrogen peroxide in the acidic medium is based on the following reactions (9 and 10) [74].

$$
\begin{aligned}
& 2 \mathrm{CuFeS}_{2}+17 \mathrm{H}_{2} \mathrm{O}_{2}+2 \mathrm{H}^{+} \rightarrow 2 \mathrm{Cu}^{2+}+2 \mathrm{Fe}^{3+}+4 \mathrm{SO}_{4}{ }^{2-}+18 \mathrm{H}_{2} \mathrm{O} \\
& 2 \mathrm{CuFeS}_{2}+5 \mathrm{H}_{2} \mathrm{O}_{2}+10 \mathrm{H}^{+} \rightarrow 2 \mathrm{Cu}^{2+}+2 \mathrm{Fe}^{3+}+4 \mathrm{~S}^{0}+10 \mathrm{H}_{2} \mathrm{O}
\end{aligned}
$$

From the presented dissolution mechanism of chalcopyrite, it can be observed that part of the sulphide sulphur is transformed into sulphate (reaction 9), whereas, according to reaction (10), sulphide sulphur is oxidized to the elemental form. The oxidizing ability of hydrogen peroxide in the acidic medium is based on the following reduction reaction (11):

$$
\mathrm{H}_{2} \mathrm{O}_{2}+2 \mathrm{H}^{+}+2 e^{-} \rightarrow 2 \mathrm{H}_{2} \mathrm{O}
$$

In very dilute solutions, hydrogen peroxide dissociates to reactive radicals according to the following reaction (12):

$$
\mathrm{H}_{2} \mathrm{O}_{2(a q)} \rightarrow \mathrm{H}^{+}(a q)+\mathrm{HO}_{2(a q)}^{-}
$$

The resulting $\mathrm{HO}_{2 \text { (aq) }}^{-}$peroxide radical reacts with the sulphide ion according to reaction (13), releasing elemental sulphur, whereas copper ions react with sulphur according to the following reaction (14):

$$
\mathrm{HO}^{-}{ }_{2(a q)}+\mathrm{S}_{(s)}^{2-} \rightarrow \mathrm{S}_{(s)}+\mathrm{H}_{2} \mathrm{O}
$$




$$
\mathrm{Cu}^{2+}{ }_{(a q)}+\mathrm{SO}_{4}{ }^{2-}{ }_{4(a q)} \rightarrow \mathrm{CuSO}_{4(a q)}
$$

General observations concerning the achieved results of chalcopyrite oxidation in the presence of hydrogen peroxide show that with increasing hydrogen peroxide concentrations, the chalcopyrite oxidation rate in sulphuric acid solutions increases [14, $30,77]$. Based on the obtained results of the leaching of chalcopyrite with hydrogen peroxide (0.1-6 $\mathrm{M} \mathrm{H}_{2} \mathrm{SO}_{4} ; 10-30 \% \mathrm{H}_{2} \mathrm{O}_{2}$; temperature 303-353 $\mathrm{K}$; stirring speed 300 , 400 and $700 \mathrm{~min}^{-1}$; particle size 100, 150, 200 and $300 \mu \mathrm{m}$ ) Adebayo et al. [30] determined that the reaction orders were 0.77 and 1.45 concerning the concentration of $\mathrm{H}_{2} \mathrm{SO}_{4}$ and $\mathrm{H}_{2} \mathrm{O}_{2}$, respectively. It was found that there is a linear relationship between the reaction rate constant and the inverse diameter of particles. The oxidation kinetics was found to follow a shrinking core model with the surface chemical reaction as the rate controlling step.

Increase of the $\mathrm{H}_{2} \mathrm{O}_{2}$ concentration ( $\left.0.1-5 \mathrm{M}\right)$ accelerates chalcopyrite oxidation in a solution of sulphuric acid $\left(0.5-3 \mathrm{M} \mathrm{H}_{2} \mathrm{SO}_{4} ; 0.1-5 \mathrm{M} \mathrm{H}_{2} \mathrm{O}_{2}\right.$; temperature $40{ }^{\circ} \mathrm{C}$; size class $-0.063+0.053 \mathrm{~mm}$; leaching time $180 \mathrm{~min}$ ) [31]. The reaction order with respect to the sulphuric acid concentration is 0.3 . The reaction order was also determined with respect to the concentration of hydrogen peroxide, and it is approximately $1(0.98)$.

The obtained activation energy value in the system of sulphuric acid - hydrogen peroxide of $39 \mathrm{~kJ} / \mathrm{mol}$ [30] indicates that the oxidation process is under chemical control. The higher activation energy of $60 \mathrm{~kJ} / \mathrm{mol}$ was obtained by Antonijević et al. [31]. The authors indicate that the oxidation process is under chemical control.

However, a problem that most researchers point out in chalcopyrite oxidation by hydrogen peroxide is that rapid exothermic decomposition of hydrogen peroxide occurs at elevated temperatures (mostly above $60^{\circ} \mathrm{C}$ ). In order to avoid the rapid decomposition of hydrogen peroxide, Mahajan et al. [74] used ethylene glycol in leaching of chalcopyrite $\left(1 \mathrm{M} \mathrm{H}_{2} \mathrm{SO}_{4}-0.26 \mathrm{M} \mathrm{H}_{2} \mathrm{O}_{2}\right)$. The addition of ethylene glycol at $65^{\circ} \mathrm{C}$ increases the copper extraction from $20 \%$ to $60 \%$ during $240 \mathrm{~min}$ of leaching. The problem of rapid decomposition of hydrogen peroxide is also pointed out by other authors [75]. Agacayak et al. [75] were carried out leaching experiments (temperature in the range from 30 to $70{ }^{\circ} \mathrm{C}, 2 \mathrm{M} \mathrm{H}_{2} \mathrm{O}_{2}$ ) and obtained the copper extraction above $80 \%$ for a period of 90 min of leaching at $40^{\circ} \mathrm{C}$. During 90-240 min of leaching, copper extraction reaches stable values, whereas with an increase in temperature in the range of $50-70^{\circ} \mathrm{C}$, copper extraction decreases compared to the obtained values at lower temperatures [75]. These results indicate that hydrogen peroxide more easily decomposes at higher temperatures, which has been confirmed by other authors as well $[31,74]$.

Solis-Marcial and Lapidus studied the sulphuric acid-hydrogen peroxideethylene glycol system for chalcopyrite oxidation [76]. The authors performed chemical and electrochemical investigations. Chalcopyrite concentrate was used in leaching experiments under the following conditions: 0.5-2.5 $\mathrm{M} \mathrm{H}_{2} \mathrm{SO}_{4} ; \mathrm{H}_{2} \mathrm{O}_{2}$ concentration 0.7 M, 1.4 M, and 2.1 M; particle size $\sim 165 \mu \mathrm{m}$ ). The results showed that $\sim 65 \%$ of copper was leached for 60 minutes when ethylene glycol was added to the solution $(1.25 \mathrm{M}$ $\mathrm{H}_{2} \mathrm{SO}_{4}-2.1 \mathrm{M} \mathrm{H}_{2} \mathrm{O}_{2}$ ). 


\subsubsection{Sulphuric acid - potassium dichromate}

Oxidative dissolution of chalcopyrite by dichromate ions $\left(\mathrm{Cr}_{2} \mathrm{O}_{7}{ }^{2-}\right)$ in an acidic medium lead to the formation of elemental sulphur or sulphate, according to the following reactions (15 and 16) [34, 77, 78]:

$6 \mathrm{CuFeS}_{2}+5 \mathrm{Cr}_{2} \mathrm{O}_{7}{ }^{2-}+70 \mathrm{H}^{+} \leftrightarrow 6 \mathrm{Cu}^{2+}+6 \mathrm{Fe}^{3+}+12 \mathrm{~S}^{0}+10 \mathrm{Cr}^{3+}+35 \mathrm{H}_{2} \mathrm{O}$

$6 \mathrm{CuFeS}_{2}+17 \mathrm{Cr}_{2} \mathrm{O}_{7}^{2-}+142 \mathrm{H}^{+} \leftrightarrow 6 \mathrm{Cu}^{2+}+6 \mathrm{Fe}^{3+}+12 \mathrm{SO}_{4}{ }^{2-}+34 \mathrm{Cr}^{3+}+71 \mathrm{H}_{2} \mathrm{O}$

Reduction of dichromate ions takes place in acidic solutions (reaction 17):

$\mathrm{Cr}_{2} \mathrm{O}_{7}^{2-}+14 \mathrm{H}^{+}+6 e^{-} \rightarrow 2 \mathrm{Cr}^{3+}+7 \mathrm{H}_{2} \mathrm{O} \quad \mathrm{E}^{0}=1.33 \mathrm{~V}$

From the presented dissolution mechanism, it can be seen that sulphide sulphur oxidizes to the elemental sulphur and sulphate, whereby the authors consider that reaction (15), in which elemental sulphur is formed, is more dominant.

Aydogan et al. [34] investigated the kinetics of chalcopyrite leaching in the acidic solution of potassium dichromate. It was determined that the reaction rate increases with increasing sulphuric acid concentration, dichromate ion concentration, temperature, and decreasing particle size. During the leaching period of 150 minutes at $90{ }^{\circ} \mathrm{C}$, the copper extraction of $80 \%$ was achieved (particle size below $75 \mu \mathrm{m}$ ). The diffusion model can describe the dissolution kinetics through a porous sulphur layer. The activation energy of this dissolution process was $24 \mathrm{~kJ} / \mathrm{mol}$.

However, the results of the previous studies showed that the chalcopyrite oxidation rate does not depend on the concentration of potassium dichromate. Chalcopyrite oxidation rate depends on the concentration of sulphuric acid, whereas the reaction order, concerning acid concentration, ranges from 0.8 to 0.92 [77]. Addition of chloride ions in the form of $\mathrm{KCl}(0.014,0.028$, and $0.056 \mathrm{M})$ in the solution $\left(0.2 \mathrm{M} \mathrm{K}_{2} \mathrm{Cr}_{2} \mathrm{O}_{7}\right.$ and $0.5 \mathrm{M}$ $\mathrm{H}_{2} \mathrm{SO}_{4}$, temperature $313 \mathrm{~K}$ ) does not increase chalcopyrite oxidation. On the other hand, with the addition of larger amounts of chloride ions $(0.141,0.197$, and $0.395 \mathrm{M})$, the rate of chalcopyrite oxidation is decreased. Also, Antonijević [79] examined chalcopyrite oxidation by sodium dichromate in perchloric acid. It was found that chalcopyrite oxidizes rapidly at temperatures higher than $60{ }^{\circ} \mathrm{C}$, whereas activation energy is 77 $\mathrm{kJ} / \mathrm{mol}$. The reaction order with respect to the perchloric acid concentration was 1.35 , and the concentration of dichromate ions does not affect the chalcopyrite oxidation rate.

Based on the obtained values of activation energy in the acidic solution of potassium dichromate, it can be said that two regimes can control the chalcopyrite dissolution process: diffusion [34] and chemical [77].

2.2.2.3. Sulphuric acid - chlorate ions

The reduction potential of chlorate ion is $1.451 \mathrm{~V}$, and it represents a strong oxidant that has found application in the oxidation of chalcopyrite. This oxidant was examined by Kariuki et al. [35] in the chalcopyrite leaching process in sulphuric acid solution. The experiments were carried out under the following conditions: $10 \mathrm{~g} / \mathrm{dm}^{3} \mathrm{H}_{2} \mathrm{SO}_{4}$, up to $3 \mathrm{~g}$ $\mathrm{NaClO}_{3}$, temperature $45-200^{\circ} \mathrm{C}$. The reaction of chalcopyrite dissolution in such system is presented by the following reaction (18):

$6 \mathrm{CuFeS}_{2(s)}+17 \mathrm{NaClO}_{3}+3 \mathrm{H}_{2} \mathrm{SO}_{4} \rightarrow 3 \mathrm{Fe}_{2}\left(\mathrm{SO}_{4}\right)_{3}+6 \mathrm{CuSO}_{4}+17 \mathrm{NaCl}+3 \mathrm{H}_{2} \mathrm{O}$ 
Obtained results show that almost all copper from $2 \mathrm{~g}$ of chalcopyrite concentrate can be leached in $30 \mathrm{ml}$ of solution $\left(70 \mathrm{~g} / \mathrm{dm}^{3} \mathrm{NaClO}_{3}\right.$ and $\left.10 \mathrm{~g} / \mathrm{dm}^{3} \mathrm{H}_{2} \mathrm{SO}_{4}\right)$ for a period of $2 \mathrm{~h}$ at a temperature of $165^{\circ} \mathrm{C}$. In addition to the sulphuric acid solution, chlorate ions have also been used in the oxidation of chalcopyrite in the hydrochloric acid solution [28]. 2.2.2.4. Sulphuric acid - persulphate ion

The advantage of using persulphate ion $\left(\mathrm{S}_{2} \mathrm{O}_{8}{ }^{2-}\right)$ is reflected in the possibility that it can be obtained from sulphuric acid in the electrochemical process [80]. Persulphate ion has a high oxidation-reduction potential of $2.123 \mathrm{~V}$. Dakubo et al. [73] investigated leaching of chalcopyrite ore and concentrate in sulphuric acid at $\mathrm{pH}=2$ with $50 \mathrm{~g} / \mathrm{dm}^{3}$ $\mathrm{Na}_{2} \mathrm{~S}_{2} \mathrm{O}_{8}$. It was determined that up to $50 \%$ of $\mathrm{Cu}$ could be leached from the chalcopyrite concentrate at a temperature of $40^{\circ} \mathrm{C}$, and that increased particle size reduces copper extraction. With finer particles of chalcopyrite concentrate $(25 \mu \mathrm{m})$, up to $70 \%$ of copper was extracted, whereas copper extraction of around $25 \%$ was achieved with a particle size of $125 \mu \mathrm{m}$. Activation energy of leaching process of chalcopyrite ore in the presence of persulphate $\left(\mathrm{pH}=2 ; 10 \mathrm{~g} / \mathrm{dm}^{3} \mathrm{Na}_{2} \mathrm{~S}_{2} \mathrm{O}_{8}, 80 \%\right.$ class $-75 \mu \mathrm{m}$, temperature $23^{\circ} \mathrm{C}$ ) was 41 $\mathrm{kJ} / \mathrm{mol}[73]$.

Table 1 shows activation energy values obtained in experiments of chalcopyrite leaching in sulphate solutions in the presence of different oxidants.

Table 1. Activation energy values of chalcopyrite leaching in the sulphate medium.

\begin{tabular}{|c|c|c|c|c|c|}
\hline $\begin{array}{l}\text { Chalcopyrite } \\
\text { sample }\end{array}$ & Solution & $\begin{array}{c}\text { Temperature, } \\
{ }^{\circ} \mathrm{C}\end{array}$ & $\begin{array}{l}\text { Activation } \\
\text { energy, kJ/mol }\end{array}$ & $\begin{array}{l}\text { Process that } \\
\text { determines the } \\
\text { reaction rate }\end{array}$ & Bibliography \\
\hline concentrate & $\begin{array}{c}\mathrm{H}_{2} \mathrm{SO}_{4-} \\
\mathrm{Fe}_{2}\left(\mathrm{SO}_{4}\right)_{3}\end{array}$ & $60-90$ & 83.7 & $\begin{array}{l}\text { electrochemical } \\
\text { control }\end{array}$ & {$[56]$} \\
\hline concentrate & $\begin{array}{c}\mathrm{H}_{2} \mathrm{SO}_{4-} \\
\mathrm{Fe}_{2}\left(\mathrm{SO}_{4}\right)_{3} \\
\end{array}$ & $45-100$ & 75 & diffusion control & {$[25]$} \\
\hline \multirow[t]{5}{*}{ crystal } & $\begin{array}{c}\mathrm{H}_{2} \mathrm{SO}_{4-} \\
\mathrm{Fe}_{2}\left(\mathrm{SO}_{4}\right)_{3} \\
\end{array}$ & $50-78$ & 88 & chemical control & [66 ] \\
\hline & \multirow{4}{*}{$\begin{array}{c}\mathrm{H}_{2} \mathrm{SO}_{4-} \\
\mathrm{Fe}_{2}\left(\mathrm{SO}_{4}\right)_{3}\end{array}$} & \multirow[b]{4}{*}{$55-85$} & in the pres & nce of $\mathrm{Fe}(\mathrm{III})$ & \multirow{4}{*}[68]{} \\
\hline & & & $\begin{array}{c}21 \pm 5 \\
83 \pm 10 \\
\text { (through } \mathrm{Cu} \text { ) } \\
76 \pm 10 \\
\text { (through } \mathrm{Fe} \text { ) }\end{array}$ & $\begin{array}{l}\text { mixed control } \\
\text { chemical control }\end{array}$ & \\
\hline & & & \multicolumn{2}{|c|}{ in the absence of $\mathrm{Fe}(\mathrm{III})$} & \\
\hline & & & $\begin{array}{c}80 \pm 10 \\
\text { (through } \mathrm{Cu} \text { ) } \\
84 \pm 10 \\
\text { (through Fe) }\end{array}$ & chemical control & \\
\hline crystal & $\begin{array}{c}\mathrm{H}_{2} \mathrm{SO}_{4-} \\
\mathrm{Fe}_{2}\left(\mathrm{SO}_{4}\right)_{3} \\
\end{array}$ & $50-90$ & $\begin{array}{l}76.5 \\
79.5 \\
\end{array}$ & - & {$[41]$} \\
\hline ore & $\begin{array}{c}\mathrm{H}_{2} \mathrm{SO}_{4-} \\
\mathrm{Na}_{2} \mathrm{~S}_{2} \mathrm{O}_{8} \\
\end{array}$ & $23-45$ & 41 & & [73] \\
\hline concentrate & $\begin{array}{c}\mathrm{H}_{2} \mathrm{SO}_{4}-\mathrm{NaCl}- \\
\mathrm{O}_{2} \\
\end{array}$ & $85-100$ & 76 & - & [86] \\
\hline
\end{tabular}




\begin{tabular}{|c|c|c|c|c|c|}
\hline $\begin{array}{l}\text { Chalcopyrite } \\
\text { sample }\end{array}$ & Solution & $\begin{array}{c}\text { Temperature, } \\
{ }^{\circ} \mathrm{C}\end{array}$ & $\begin{array}{l}\text { Activation } \\
\text { energy, } \mathrm{kJ} / \mathrm{mol}\end{array}$ & $\begin{array}{l}\text { Process that } \\
\text { determines the } \\
\text { reaction rate }\end{array}$ & Bibliography \\
\hline concentrate & $\begin{array}{l}\mathrm{H}_{2} \mathrm{SO}_{4-} \\
\mathrm{K}_{2} \mathrm{Cr}_{2} \mathrm{O}_{7}\end{array}$ & $30-80$ & $48-54$ & chemical control & [77] \\
\hline \begin{tabular}{|l} 
natural \\
sample
\end{tabular} & $\begin{array}{l}\mathrm{H}_{2} \mathrm{SO}_{4-} \\
\mathrm{K}_{2} \mathrm{Cr}_{2} \mathrm{O}_{7}\end{array}$ & $25-60$ & 50 & chemical control & [85] \\
\hline concentrate & $\mathrm{H}_{2} \mathrm{SO}_{4}-\mathrm{H}_{2} \mathrm{O}_{2}$ & $25-50$ & 60 & chemical control & [31] \\
\hline concentrate & $\mathrm{H}_{2} \mathrm{SO}_{4}-\mathrm{H}_{2} \mathrm{O}_{2}$ & $30-80$ & 39 & chemical control & [30] \\
\hline $\begin{array}{l}\text { natural } \\
\text { sample }\end{array}$ & \begin{tabular}{|c|}
$\mathrm{H}_{2} \mathrm{SO}_{4}-\mathrm{H}_{2} \mathrm{O}_{2}-$ \\
ethylene \\
glycol
\end{tabular} & $25-75$ & 30 & chemical control & [74] \\
\hline concentrate & $\mathrm{H}_{2} \mathrm{SO}_{4}-\mathrm{CuCl}_{2}$ & $55-90$ & $24.4-29.4$ & diffusion control & [84] \\
\hline crystal & $\mathrm{H}_{2} \mathrm{SO}_{4}$ & $35-68$ & 130.70 & mixed control & [82] \\
\hline concentrate & $\mathrm{H}_{2} \mathrm{SO}_{4}$ & $48-85$ & 78 & chemical control & [83] \\
\hline concentrate & $\mathrm{H}_{2} \mathrm{SO}_{4}-\mathrm{H}_{2} \mathrm{O}_{2}$ & $25-45$ & 80 & diffusion control & [14] \\
\hline
\end{tabular}

\subsection{Leaching of chalcopyrite in chloride solutions}

The application of chloride solutions in the hydrometallurgical processing of sulphide concentrates is very important [16]. By comparing the kinetics of the leaching process in the chloride and sulphate medium, it was determined that chalcopyrite leaches faster in the chloride medium. The leaching of chalcopyrite in the chloride medium can be carried out at atmospheric pressure and room temperature, and, at the same time, there is a possibility of reuse of the reagent in the leaching process. Significant advantages of the application of chloride systems are: a) high solubility of copper and iron; b) faster oxidation of Fe (II) ions to Fe (III) ions; c) formation of a more porous sulphur layer as a reaction product that allows the diffusion of reactants to the reaction surface, and d) faster kinetics of chalcopyrite leaching compared to sulphate systems [16, 87].

Although many processes for obtaining copper from concentrates have been studied and developed [81] not all processes have come to life at the industrial level due to the following disadvantages and limitations: a) corrosive effect of chloride, which requires the use of expensive construction materials for reactors; b) the need for fine grinding for processes conducted under atmospheric pressure; c) co-leaching of multiple elements present in concentrates which require additional treatment of the solution and e) difficult electrolysis of high-quality copper from the chloride solution.

In chloride solution, $\mathrm{Fe}$ (III) ions in the form of $\mathrm{Fe}$ (III) chloride and $\mathrm{Cu}$ (II) ions in the form of $\mathrm{Cu}$ (II) chloride are most often used as oxidants. It is considered that chalcopyrite leaching is significantly more efficient in chloride solutions where $\mathrm{Cu}$ (II) ions are present as an oxidant rather than in sulphate solutions where Fe (III) ions are present as an oxidant [90]. 
The mechanism of chalcopyrite dissolution in chloride solutions is described through the following reactions (19-21) [17]:

$\mathrm{CuFeS}+3 \mathrm{FeCl}_{3} \rightarrow \mathrm{CuCl}+4 \mathrm{FeCl}_{2}+2 \mathrm{~S}^{0}$

$\mathrm{CuFeS}_{2}+4 \mathrm{FeCl}_{3} \rightarrow \mathrm{CuCl}_{2}+5 \mathrm{FeCl}_{2}+2 \mathrm{~S}^{0}$

$\mathrm{CuFeS}+3 \mathrm{CuCl}_{2} \rightarrow 4 \mathrm{CuCl}+\mathrm{FeCl}_{2}+2 \mathrm{~S}^{0}$

The redox potential of $\mathrm{Cu}^{2+} / \mathrm{Cu}^{+}$couple is significantly higher in chloride than in sulphate solution. Also, the redox potential of $\mathrm{Cu}^{2+} / \mathrm{Cu}^{+}$is higher than the redox potential of $\mathrm{Fe}^{3+} / \mathrm{Fe}^{2+}$ in saturated chloride solution. This increase in redox potential $\left(\mathrm{Cu}^{2+} / \mathrm{Cu}^{+}\right)$is a consequence of a very strong complex of $\mathrm{Cu}$ (I) ions with chloride ions. The dominant chloride complexes of copper and iron that occur in a strong chloride solution are: $\mathrm{CuCl}_{3}{ }^{2}$, $\mathrm{CuCl}^{+}, \mathrm{CuCl}_{2}, \mathrm{FeCl}_{2}$, and $\mathrm{FeCl}_{2}{ }^{+}$[90]. Winand [91] achieved higher copper extractions by leaching chalcopyrite in the presence of chloride ions due to the formation of a complex of copper with $\mathrm{Cl}^{-}$ions, which led to the higher solubility of copper in the $\mathrm{Cu}$ (I) $-\mathrm{Cu}$ (II) $-\mathrm{Cl}^{-}$system.

2.3.1. Fe (III) chloride solutions

The major reaction product of chalcopyrite leaching in Fe (III) chloride solution is elemental sulphur (reactions 19-21). Habashi [92] found that the leaching rate of chalcopyrite with $\mathrm{Fe}$ (III) chloride shows a parabolic dependence caused by the progressive formation of an elemental sulphur layer at the solid-liquid interface, where this layer is not completely compact and can be removed by mixing the solution. In $\mathrm{Fe}$ (III) chloride solution, the dissolution rate is independent of temperature in the range of $45-100^{\circ} \mathrm{C}$, and it is independent of acid concentration as well, but directly proportional to the surface area of chalcopyrite particles. The obtained activation energy in this chloride solution $(42 \mathrm{~kJ} / \mathrm{mol})$ is lower than the energy obtained in the sulphate solution $\left(0.1 \mathrm{M} \mathrm{Fe}_{2}\left(\mathrm{SO}_{4}\right)_{3}\right.$ and $\left.0.3 \mathrm{M} \mathrm{H}_{2} \mathrm{SO}_{4}\right)$ which is $75 \mathrm{~kJ} / \mathrm{mol}$ which indicates to a faster oxidation reaction in chloride solution [25].

In the $\mathrm{FeCl}_{3}-\mathrm{HCl}$ solution (0-2 $\mathrm{M} \mathrm{FeCl}_{3}, 0-3 \mathrm{M} \mathrm{HCl}$, leaching time 0-90 h), it was found that more than $95 \%$ of sulphur and less than $5 \%$ of sulphate are formed [88]. The surface of chalcopyrite particles is quickly covered with a layer of elemental sulphur during leaching. The morphology of the resulting sulphur layer does not depend on the concentration of Fe (III) chloride or hydrochloric acid. However, other authors [94, 95] determined that the dissolution rate of chalcopyrite depends on the concentration of $\mathrm{Fe}$ (III)-chloride, and that it is independent of the concentration of Fe (II)-chloride. The reaction order with respect to the concentration of Fe (III)-chloride was 0.5.

The results of the effect of the concentration of $\mathrm{Fe}(\mathrm{III})$ ions $\left(0.02-0.50 \mathrm{M} \mathrm{FeCl}_{3}\right.$ in a solution of $1 \mathrm{M} \mathrm{HCl}$ and $3 \mathrm{M} \mathrm{NaCl})$ and the effect of the concentration of $\mathrm{NaCl}(0-2 \mathrm{M}$ $\mathrm{NaCl}$ in a solution of $0.2 \mathrm{M} \mathrm{HCl}$ and $0.2 \mathrm{M} \mathrm{FeCl}_{3}$ ) on the kinetics of chalcopyrite dissolution indicated that electrochemical reactions on the chalcopyrite surface determine the process of chalcopyrite leaching [96]. The following anodic and cathodic reactions take place in this system (22-26): 
It was found that linear kinetics occur and that the reaction rate depends on the concentration of $\mathrm{Fe}$ (III) ions (reaction order is 0.5). The reaction rate increases with increasing $\mathrm{NaCl}$ concentration to $1 \mathrm{M}$. In a solution of $1 \mathrm{M} \mathrm{HCl}$ and $3 \mathrm{M} \mathrm{NaCl}$, the activation energy is $83 \mathrm{~kJ} / \mathrm{mol}$, while in a solution of $0.2 \mathrm{M} \mathrm{HCl}$, the value of activation energy is $62 \mathrm{~kJ} / \mathrm{mol}[96]$.

Baba et al. [97] examined the dissolution kinetics of chalcopyrite in hydrochloric acid solution. The effect of temperature $\left(27-80^{\circ} \mathrm{C}\right)$, the effect of acid concentration $(0.1-8.42 \mathrm{M} \mathrm{HCl})$, and the effect of particle size (classes $-90+75 \mu \mathrm{m},-112+90 \mu \mathrm{m}$ and $-300+112 \mu \mathrm{m})$ on chalcopyrite dissolution were investigated. The dissolution rate increase with increasing $\mathrm{HCl}$ concentration and temperature and with decreasing particle size. Under optimal leaching conditions $\left(4 \mathrm{M} \mathrm{HCl}, 80^{\circ} \mathrm{C}\right.$, size class $-90+75 \mu \mathrm{m}$, leaching time 120 minutes), about $91.33 \% \mathrm{Cu}$ was leached. The dissolution process is under diffusion control with an activation energy of $31.6 \mathrm{~kJ} / \mathrm{mol}$. The reaction order respect to $\mathrm{HCl}$ concentrations is 0.42 .

\subsubsection{Cu (II) chloride solutions}

In addition to Fe (III) chloride, the second most commonly used oxidant in chalcopyrite leaching is $\mathrm{Cu}$ (II) chloride [89, 90, 98, 99]. It is considered that the dissolution of chalcopyrite in acidic $\mathrm{Cu}$ (II) solutions take place according to reaction (27) whereby a copper complex is formed $\mathrm{CuCl}_{3}{ }^{2-}$ :

$$
\mathrm{CuFeS} \mathrm{F}_{(s)}+3[\mathrm{CuCl}]_{(a q)}^{+}+11 \mathrm{Cl}_{(a q)}^{-}=4\left[\mathrm{CuCl}_{3}\right]_{\left({ }_{(a q)}\right.}+\mathrm{FeCl}_{2(a q)}+2{S_{(s)}^{0}}
$$

It was determined that $\mathrm{Cu}$ (II) ions do not affect the dissolution rate of chalcopyrite in the concentration range $0.79-1.46 \mathrm{M}$, and $\mathrm{Cu}(\mathrm{I})$ ions in the concentration range 2.82 $6.21 \mathrm{M}\left(\right.$ at $\left.90^{\circ} \mathrm{C}\right)$. The ratio of $\mathrm{Cu}(\mathrm{II}) / \mathrm{Cu}$ (I) concentrations should be less than 1.9 in order for reaction (27) to be possible from a thermodynamic point of view [90]. As the concentration of copper in the solution increases, the stability of $\mathrm{Cu}$ (II) ions decreases, and the formation of copper complexes, $\left[\mathrm{CuCl}^{+}\right]$and $\left[\mathrm{CuCl}_{2}^{-}\right]$, mainly occurs. The obtained complex $\left[\mathrm{CuCl}_{2}{ }^{-}\right]$is more stable at $90^{\circ} \mathrm{C}$ than at $25^{\circ} \mathrm{C}$, while the changes in the stability of the obtained complexes in the temperature range of $25-90^{\circ} \mathrm{C}$ are small.

High copper extraction values were achieved by oxidation of chalcopyrite in chloride solutions. For example, Padilla et al. [100] investigated the leaching process of chalcopyrite in a $\mathrm{CuCl}_{2}-\mathrm{NaCl}-\mathrm{O}_{2}$ solution at atmospheric pressure and temperature up to $105^{\circ} \mathrm{C}$ and obtained $93 \%$ of copper (size class -400 mesh, $2 \mathrm{~h}$ of leaching). As the flow of oxygen in the solution increases to $0.11 \mathrm{~min}$, the dissolution rate also increases. Also, 
it is pointed out that the rate of agitation does not have a significant effect on the dissolution rate, while the concentration of chloride up to $4 \mathrm{M}$ affects the dissolution kinetics.

Skrobian et al. [101] also found that with increasing $\mathrm{NaCl}$ concentration, metal extraction from chalcopyrite concentrate also increases. No presence of a solid layer of the product was observed on the chalcopyrite particles, which would affect the reduction of the dissolution rate.

Velasquez - Yevenes et al. [98] leached four concentrates of chalcopyrite in chloride solutions with $\mathrm{Cu}$ (II) ions and dissolved oxygen $\left(0.2 \mathrm{M} \mathrm{HCl}\right.$ and $0.5 \mathrm{~g} / \mathrm{dm}^{3} \mathrm{Cu}$ (II), 5-15 $\mathrm{mg} / 1 \mathrm{O}_{2}$, temperature $35^{\circ} \mathrm{C}$, agitation speed $800 \mathrm{~min}^{-1}$ ) and determined that the oxidation rate of chalcopyrite increases significantly in the potential range from $550 \mathrm{mV}$ to $620 \mathrm{mV}$ (SHE). The authors found that the presence of dissolved oxygen in the system contributes to more efficient copper extraction. However, although dissolved oxygen has a positive effect on increasing copper extraction, excess oxygen is undesirable because it can lead to an increase in redox potential, and thus to surface passivation. At potentials above $630 \mathrm{mV}$, the dissolution rate is low. In the continuation of the research of the mentioned authors [99] in a solution of $\mathrm{HCl}(0.2 \mathrm{M} \mathrm{HCl}+0.008 \mathrm{M} \mathrm{Cu}$ (II); temperature $35^{\circ} \mathrm{C}$ ), it was shown that a low concentration of $\mathrm{Cu}$ (II) ions contributes to the acceleration of the dissolution kinetics of chalcopyrite, while a further increase in the concentration of $\mathrm{Cu}$ (II) ions does not affect the increase in the oxidation kinetics. Nicol et al. [102] also found that a low concentration of $\mathrm{Cu}$ (II) ions in a solution $(0.1 \mathrm{~g} / \mathrm{l})$ leads to an increase in copper extraction but that higher concentrations of $\mathrm{Cu}$ (II) ions do not have a significant effect on the reaction rate. The addition of $\mathrm{Cu}$ (II) ions leads to the formation of an intermediate product, $\mathrm{Cu}_{2} \mathrm{~S}$, at lower potentials (about $560 \mathrm{mV}$, SHE), which leads to an increase in the reaction rate because of the resulting $\mathrm{Cu}_{2} \mathrm{~S}$ oxidizes much faster than $\mathrm{CuFeS}_{2}$ [103].

Recent research by Turan et al. [104] shows that chloride ions contribute to the oxidation of chalcopyrite in ammonium persulphate solution, which acted as an oxidizing agent. In such a leach system, the reactions (28 and 29) take place and released Fe (II) ions oxidize to Fe (III) ions, while sulphur is oxidized to sulphate.

$$
\begin{aligned}
& 2 \mathrm{Fe}^{2+}+\mathrm{S}_{2} \mathrm{O}_{8}^{2-} \rightarrow 2 \mathrm{Fe}^{3+}+2 \mathrm{SO}_{4}{ }^{2-} \\
& \mathrm{S}^{0}+3 \mathrm{~S}_{2} \mathrm{O}_{8}{ }^{2-}+4 \mathrm{H}_{2} \mathrm{O} \rightarrow 7 \mathrm{SO}_{4}^{2-}+8 \mathrm{H}^{+}
\end{aligned}
$$

An increase in the concentration of $\mathrm{NaCl}$ and $\left(\mathrm{NH}_{4}\right)_{2} \mathrm{~S}_{2} \mathrm{O}_{8}$ was found to have a positive effect on metal extraction. It should be emphasized that with increasing temperature up to $60^{\circ} \mathrm{C}$, an increase in metal extraction in solution was observed, while above this value, metal extraction decreases, most likely due to the decomposition of ammonium persulphate. Under optimal leaching conditions $(150 \mathrm{~g} / \mathrm{l} \mathrm{NaCl}, 250 \mathrm{~g} / \mathrm{l}$ $\left(\mathrm{NH}_{4}\right)_{2} \mathrm{~S}_{2} \mathrm{O}_{8}, 60^{\circ} \mathrm{C}$, liquid/solid $=250 \mathrm{ml} / \mathrm{g}$, agitation rate $400 \mathrm{~min}^{-1}$, leaching time 180 minutes) $75 \%$ of $\mathrm{Cu}$ and $80 \%$ of $\mathrm{Fe}$ were leached. In contrast, in the absence of chloride ions, only $14 \%$ of $\mathrm{Cu}$ and $21 \%$ of $\mathrm{Fe}\left(250 \mathrm{~g} / \mathrm{l}(\mathrm{NH} 4) 2 \mathrm{~S} 2 \mathrm{O} 8,60^{\circ} \mathrm{C}\right.$, liquid/solid $=10 \mathrm{ml} / \mathrm{g}$, agitation rate $400 \mathrm{~min}^{-1}$, leaching time 200 minutes) were leached. The positive influence of chloride ions on chalcopyrite leaching was also observed by other researchers [105]. 
Chlorate was also used for the oxidation of chalcopyrite concentrates in chloride solutions [28]. In a solution of hydrochloric acid and sodium chlorate, chalcopyrite is dissolved according to reaction (30):

$$
\begin{aligned}
& 6 \mathrm{CuFeS} S_{(s)}+17 \mathrm{NaClO}_{3(a q)}+30 \mathrm{HCl}_{(a q)} \rightarrow \\
& \rightarrow 6 \mathrm{CuCl}_{2(a q)}+6 \mathrm{FeCl}_{3(a q)}+17 \mathrm{NaCl}_{(a q)}+12 \mathrm{H}_{2} \mathrm{SO}_{4(a q)}+3 \mathrm{H}_{2} \mathrm{O}_{(l)}
\end{aligned}
$$

As a product of reaction (30), $\mathrm{FeCl}_{3}$ is formed, ie the formed $\mathrm{Fe}$ (III) ions represent an oxidizing agent. Therefore, alternating oxidation and reduction of $\mathrm{Fe}^{3+} / \mathrm{Fe}^{2+}$ couple in solution takes place via the following reactions (31 and 32):

$$
\begin{aligned}
& 6 \mathrm{FeCl}_{2(s)}+\mathrm{NaClO}_{3(a q)}+6 \mathrm{HCl}_{(a q)} \rightarrow 3 \mathrm{FeCl}_{3(a q)}+\mathrm{NaCl}_{(a q)}+3 \mathrm{H}_{2} \mathrm{O}_{(l)} \\
& \mathrm{CuFeS}_{2(s)}+\mathrm{FeCl}_{3(a q)} \rightarrow \mathrm{CuCl}_{2(a q)}+\mathrm{FeCl}_{2}(\mathrm{aq})+\mathrm{S}_{(s)}
\end{aligned}
$$

In the $\mathrm{HCl}-\mathrm{NaClO}_{3}$ system, about $45 \%$ of $\mathrm{Cu}\left(1 \mathrm{M} \mathrm{HCl}+0.5 \mathrm{M} \mathrm{NaClO}_{3}\right)$ was leached after $5 \mathrm{~h}$, while about $65 \%$ of $\mathrm{Cu}$ was leached in a solution of $1 \mathrm{M} \mathrm{HCl}+1 \mathrm{M}$ $\mathrm{NaClO}_{3}$. The dissolution rate of chalcopyrite increases with increasing concentration of $\mathrm{HCl}$ and $\mathrm{NaClO}_{3}$, whereby both, particle size (size classes:-0.1+0.074 mm, $-0.074+0.043$ $\mathrm{mm}$ and $-0.043+0.038 \mathrm{~mm}$ ) and temperature (from $25^{\circ} \mathrm{C}$ to $85^{\circ} \mathrm{C}$ ), affect the dissolution rate of chalcopyrite. X-ray diffraction analysis indicated that sulphide is oxidised to sulphate at temperatures less than or equal to $65^{\circ} \mathrm{C}$, and it is oxidised to elemental sulphur at $85^{\circ} \mathrm{C}$ in the leaching process [28].

Shiers et al. [106] investigated the oxidation of chalcopyrite concentrate (size class $-53+35 \mu \mathrm{m}$ ) and chalcopyrite ore (size class - $200 \mu \mathrm{m}$ ) in hypochlorous acid solution, sodium chlorate and potassium nitrate with and without Fe (III) ions. Leaching of chalcopyrite in hypochlorous acid solution, at $\mathrm{pH} 4-6$, takes place according to the following reactions (33 and 34):

$$
\begin{aligned}
& 2 \mathrm{CuFeS}_{2}+11 \mathrm{HClO} \rightarrow 2 \mathrm{Cu}^{2+}+\mathrm{Fe}_{2} \mathrm{O}_{3}+2 \mathrm{SO}_{4}^{2-}+2 \mathrm{~S}+11 \mathrm{Cl}^{-}+11 \mathrm{H}^{+} \\
& 2 \mathrm{CuFeS}_{2}+17 \mathrm{HClO}+2 \mathrm{H}_{2} \mathrm{O} \rightarrow 2 \mathrm{Cu}^{2+}+\mathrm{Fe}_{2} \mathrm{O}_{3}+4 \mathrm{SO}_{4}^{2-}+21 \mathrm{H}^{+}+17 \mathrm{Cl}^{-}
\end{aligned}
$$

At slightly higher $\mathrm{pH}$, hypochlorous acid decomposes to $\mathrm{Cl}_{2}$, which causes reduction of the selectivity of leaching and leads to the dissolution of both copper and iron (reaction 35)

$2 \mathrm{CuFeS}_{2}+17 \mathrm{Cl}_{2}+16 \mathrm{H}_{2} \mathrm{O} \rightarrow 2 \mathrm{CuCl}_{2}+2 \mathrm{FeCl}_{3}+4 \mathrm{H}_{2} \mathrm{SO}_{4}+24 \mathrm{HCl}$

The obtained results indicate that hypochlorous acid is the most aggressive medium for chalcopyrite leaching. The extraction of copper reached $\sim 100 \%$ during the leaching of chalcopyrite concentrate $(1-5 \mathrm{~h}$ of leaching at room temperature at a hypochloric acid concentration of 0.3-0.4 M). Using chlorate as an oxidant, it was shown that $72 \%$ of $\mathrm{Cu}\left(0.4 \mathrm{M} \mathrm{NaClO}_{3}+0.1 \mathrm{M} \mathrm{Fe}\left(\mathrm{NO}_{3}\right)_{3}\right)$ was extracted. In the nitrate solution after $168 \mathrm{~h}$ of leaching, 35-40\% $\mathrm{Cu}$ was extracted. On the other hand, by leaching chalcopyrite ore, it was determined that the most suitable leaching medium is a nitrate 
solution $\left(0.6 \mathrm{M} \mathrm{KNO}_{3}+0.1 \mathrm{M} \mathrm{FeCl}_{3}\right)$ where $92 \%$ of $\mathrm{Cu}$ is achieved, followed by the system of $\mathrm{ClO}_{3}^{-} / \mathrm{Fe}\left(\mathrm{NO}_{3}\right)_{3}$ with a $67 \%$ of $\mathrm{Cu}$ leached $\left(50^{\circ} \mathrm{C}, 120 \mathrm{~h}\right)$ and finally $\mathrm{HClO}$ with $56 \%$ of $\mathrm{Cu}\left(30^{\circ} \mathrm{C}, 24 \mathrm{~h}\right)$. All examined oxidants are significantly more efficient for chalcopyrite leaching than $\mathrm{Fe}$ (III) sulphur - by leaching with $\mathrm{Fe}_{2}\left(\mathrm{SO}_{4}\right)_{3}$ during $168 \mathrm{~h}$ at a temperature of $50^{\circ} \mathrm{C}$ only $15 \%$ of $\mathrm{Cu}$ was extracted.

Ikiz et al. [107] examined the oxidation of chalcopyrite in hypochlorous acid solution. Under optimal leaching conditions (concentration of $\mathrm{HClO}=0.2 \mathrm{M}, \mathrm{pH}=5$, solid/liquid ratio $=4 \mathrm{~g} / \mathrm{l}$ ), copper extraction from chalcopyrite ore ranges from $40 \%$ to $80 \%$ during the first 15 minutes of the reaction. The reaction rate depends on the temperature and particle size, which is in accordance with the results of other authors [28]. The Jander equation best describes the chalcopyrite leaching process. The activation energy of $19.88 \mathrm{~kJ} / \mathrm{mol}$ was determined from the Arrhenius diagram, which indicates that the dissolution process was determined by diffusion through the layer of products (silicon and elemental sulphur layer) [107].

Li et al. [108] found that in perchoric acid solution chalcopyrite is completely dissolved at $\mathrm{pH}=1$ (temperature $75^{\circ} \mathrm{C}$, potential $750 \mathrm{mV}$, leaching time $100 \mathrm{~h}$ ) while with increasing $\mathrm{pH}$ of the solution $(\mathrm{pH}=2)$ the dissolution rate decreases significantly due to low activity of $\mathrm{Fe}^{3+}$ ions in solution resulting from previous precipitation of iron compounds.

Based on the available literature data, it can be observed that the oxidation of chalcopyrite has not been intensively studied in the $\mathrm{HCl}-\mathrm{H}_{2} \mathrm{O}_{2}$ system. The leaching system $\mathrm{HCl}-\mathrm{H}_{2} \mathrm{O}_{2}$ was applied in the leaching of pyrite concentrate [109], sulphide $\mathrm{Pb}$ $\mathrm{Zn}$ concentrate at atmospheric pressure [110], in the leaching of galena [111], and the concentrate of scheelite [112].

Petrović et al. [32] investigated the influence of agitation rate, solid to liquid ratio, acid and oxidant concentration and temperature on copper and iron extraction from chalcopyrite concentrate. It was found that in the $\mathrm{HCl}-\mathrm{H}_{2} \mathrm{O}_{2}$ system, intense oxidation of chalcopyrite takes place in the first 60 minutes of the reaction, after which the reaction rate decreases significantly due to the rapid catalytic decomposition of hydrogen peroxide. The agitation rate and reaction temperature were found to have a negligible effect on chalcopyrite dissolution, while the solid to liquid ratio significantly affected copper and iron leaching. An increase in the concentration of hydrochloric acid (0.1-3.0 $\mathrm{M})$ and hydrogen peroxide $(0.5-3.0 \mathrm{M})$ in the solutions has a positive effect on the oxidative leaching of chalcopyrite. The order of the reaction was determined to be 0.30 with respect to the concentration of acid, and 0.53 with respect to the concentration of hydrogen peroxide. The dissolution kinetics of chalcopyrite in both examined systems is successfully described by the first-order kinetics equation $X=X_{m}\left(1-e^{-k t}\right)$. The values of activation energy in chloride solutions are $19.6 \mathrm{~kJ} / \mathrm{mol}$ (via Cu), and $17.1 \mathrm{~kJ} / \mathrm{mol}$ (via Fe).

Table 2 shows activation energy values obtained in experiments of chalcopyrite leaching in chloride solutions in the presence of various oxidants. 
Table 2. Activation energy values of the chalcopyrite leaching process in chloride solutions.

\begin{tabular}{|c|c|c|c|c|c|}
\hline $\begin{array}{l}\text { Chalcopyrite } \\
\text { sample }\end{array}$ & Solution & $\begin{array}{l}\text { Tempera- } \\
\text { ture, }{ }^{\circ} \mathrm{C}\end{array}$ & $\begin{array}{l}\text { Activation } \\
\text { energy, } \\
\mathrm{kJ} / \mathrm{mol}\end{array}$ & $\begin{array}{l}\text { Process that } \\
\text { determines the } \\
\text { reaction rate }\end{array}$ & Bibliography \\
\hline $\begin{array}{l}\text { synthetic and } \\
\text { natural }\end{array}$ & $\mathrm{HCl}+\mathrm{FeCl}_{3}$ & $50-100$ & 45.9 & chemical reaction & {$[65]$} \\
\hline \multirow{2}{*}{ natural } & $\mathrm{HCl}+\mathrm{FeCl}_{3}$ & $75-96$ & 62 & \multirow{2}{*}{$\begin{array}{c}\text { electrochemical } \\
\text { control }\end{array}$} & \multirow{2}{*}{ [96] } \\
\hline & $\mathrm{HCl}+\mathrm{FeCl}_{3}+\mathrm{NaCl}$ & $82.5-96$ & 83 & & \\
\hline crystal & $\mathrm{HCl}+\mathrm{FeCl}_{3}$ & $52-85$ & 69 & $\begin{array}{c}\text { electrochemical } \\
\text { control }\end{array}$ & {$[94]$} \\
\hline concentrate & $\mathrm{HCl}+\mathrm{FeCl}_{3}$ & $65-110$ & 37.4 & chemical control & [113] \\
\hline- & $\mathrm{HCl}+\mathrm{FeCl}_{3}$ & $23-40$ & 86.4 & - & [114] \\
\hline ore & $\mathrm{HCl}+\mathrm{FeCl}_{3}$ & $30-90$ & $15-28$ & mixed control & {$[26]$} \\
\hline concentrate & $\mathrm{HCl}+\mathrm{FeCl}_{3}$ & $3.5-80$ & $55 \pm 5$ & chemical control & [115] \\
\hline- & $\mathrm{HCl}+\mathrm{Fe}(\mathrm{III})$ & $40-95$ & $48 \pm 10$ & chemical control & [116] \\
\hline concentrate & $\mathrm{FeCl}_{3}$ & $55-106$ & 40 & - & [117] \\
\hline concentrate & $\mathrm{FeCl}_{3}$ & $3.5-45$ & 1.1 & diffusion control & \multirow{2}{*}{ [118] } \\
\hline concentrate & $\mathrm{FeCl}_{3}+\mathrm{CCl}_{4}$ & $45-80$ & 68.9 & chemical control & \\
\hline concentrate & $\begin{array}{c}\mathrm{HCl}+\mathrm{FeCl}_{3}+ \\
\mathrm{NaCl}\end{array}$ & $60-90$ & 68 & - & [119] \\
\hline $\begin{array}{l}\text { concentrate } \\
\text { and crystal }\end{array}$ & $\begin{array}{c}\mathrm{HCl}+\mathrm{FeCl}_{3}+ \\
\mathrm{CuCl}_{2}\end{array}$ & $70-90$ & 69 & chemical control & {$[93]$} \\
\hline ore & $\mathrm{HClO}$ & $10-40$ & 19.88 & diffusion control & [107] \\
\hline concentrate & $\mathrm{HCl}-\mathrm{Cu}(\mathrm{II})-\mathrm{Cl}^{-}$ & $25-75$ & 72 & $\begin{array}{c}\text { chemical and } \\
\text { electrochemical } \\
\text { control }\end{array}$ & [102] \\
\hline ore & $\mathrm{HCl}$ & $25-80$ & 31.6 & diffusion control & [97] \\
\hline concentrate & $\mathrm{HCl}+\mathrm{H}_{2} \mathrm{O}_{2}$ & $30-60$ & 20 & diffusion control & [32] \\
\hline
\end{tabular}

\section{Conclusion}

Based on the obtained results of chemical dissolution of chalcopyrite in sulphate and chloride solutions, the following can be concluded:

1. Chalcopyrite leached slowly in sulphate solutions. The copper extraction values are different for the same or similar experimental conditions (temperature, leaching time, particle size), and they are range up to $90 \%$. This difference in metal extraction values can be explained by the fact that the studies were performed on different samples of chalcopyrite (different mineral composition, presence of other sulphide minerals, presence of different gangue minerals, etc.).

- The chalcopyrite dissolution rate in sulphate solution increases when $\mathrm{Fe}$ (III) ion concentration increases from 0.001 to $0.05 \mathrm{M}$, while the Fe (III) concentration increasing within the range from 0.05 to $0.5 \mathrm{M}$ leads to chalcopyrite leaching rate decreasing.

- $\quad$ According to some studies, oxidation of chalcopyrite in Fe (II) sulphate solution is more efficient than oxidation in Fe (III) sulphate solution. 
- The obtained results of chalcopyrite oxidation in the presence of strong oxidizing agents such as hydrogen peroxide indicate that with increasing oxidant concentration, the rate of chalcopyrite oxidation in sulphuric acid solutions increases, while the achieved copper extractions in the presence of hydrogen peroxide were above $80 \%$.

- $\quad$ The agitation rate can negatively affect the oxidation rate of chalcopyrite because it has been shown that peroxide decomposes more rapidly if mechanical mixing is introduced into the system. To prevent the decomposition of the oxidant, it is recommended that the temperature of the solution is kept below $60^{\circ} \mathrm{C}$ and/or to introduce an organic solvent into the solution.

- $\quad$ Results in the solution of sulfuric acid - potassium dichromate indicate that the increase in the concentration of potassium dichromate can both positively and negatively affect the rate of oxidation of chalcopyrite, while in other studies it was found that the rate of chalcopyrite oxidation in a mentioned system depends only on the concentration of sulphuric acid.

2. Sulphuric acid - chlorate system is suitable for chalcopyrite oxidation, where copper can be quantitatively leached at elevated temperature. Based on the analysis of the kinetics of chalcopyrite leaching, it was shown that chalcopyrite dissolves chemically better in the chloride medium as compared to leaching in the sulphate medium.

- In chloride solutions, linear dissolution kinetics generally occurs, including the formation of a porous sulphur layer through which the reactants and reaction products are diffused.

- High copper extractions were achieved by oxidation of chalcopyrite concentrate in chloride solutions.

- The agitation can negatively affect copper extraction in the $\mathrm{FeCl}_{3}-\mathrm{HCl}$ solution: in the conditions of solution agitation, the formed $\mathrm{Cu}$ (II)-chloride complexes that occur on the reaction surface in the reaction between the chalcopyrite particle and Fe (III) ions are removed. The concentration of $\mathrm{Cu}$ (II) ions on the reaction surface in conditions when agitation is not present in the system is high enough so that $\mathrm{Cu}$ (II) ions accelerate the dissolution kinetics, i.e. have a positive effect on the overall dissolution reaction.

3. The values of activation energies obtained in chloride solutions are lower than values of activation energy obtained in sulphate solutions, which indicates faster oxidation kinetics of chalcopyrite in chloride system. The obtained high values of activation energy clearly indicate the fact that chalcopyrite oxidation experiments should be carried out at elevated temperatures.

4. The slow kinetics of chalcopyrite leaching is a consequence of the formation of reaction products on the mineral surface, causing surface passivation. The nature of the passive layer and the mechanism of its formation have not been thoroughly explained. However, it is usually assumed that elemental sulphur, metal-deficient sulphides, polysulphides, iron compounds, or jarosite form a passive layer on the surface of chalcopyrite. 


\section{Acknowledgements}

The research presented in this paper was done with the financial support of the Ministry of Education, Science and Technological Development of the Republic of Serbia, within the funding of the scientific research work at the University of Belgrade, Technical Faculty in Bor. according to the contract with registration number 451-03-68/2020-14/ 200131

\section{References}

[1] E.M. Cordoba, H.J.A. Munoz, M.L. Blazquez, F. Gonzalez, A. Ballester: Hydrometallurgy, 93 (2008) 81-97.

[2] A.A. Baba, K.I. Ayinla, F.A. Adekola, M.K. Ghosh, O.S. Ayanda, R.B. Bale, A.R. Sheik, S.R. Pradhan: Inter J Mining Eng Miner Process, 1 (2012) 1-16.

[3] Y. Zhang, X. Zhang, L. Qiana, M. Suna, Y. Yanga, Y. Zhanga, J. Wanga, H. Kim, G. Qiua: Miner Eng, 136 (2019) 140-154.

[4] S. He, W. Skinner, D. Fornasiero: Int J Miner Process, 80 (2006) 169-176.

[5] Y. Bu, Y. Hu, W. Sun, Z. Gao, R. Liu: Minerals, 8 (2018) 115.

[6] J. Sokolović, R. Stanojlović, Lj. Andrić, Z. Štirbanović, N. Ćirić: Journal of Mining and Metallurgy A: Mining, 55 (2019) 53-65.

[7] A.Y. Li, N. Kawashima, J. Li, A.P. Chandra, A.R. Gerson: Adv Colloid Interface Sci, 197-198 (2013) 1-32.

[8] H.R.,Watling: Hydrometallurgy, 84 (1-2) (2006) 81-108.

[9] G.D. Bogdanović, V. Stanković, M.S. Trumić, D.V. Antić., M.Ž. Trumić: Journal of Mining and Metallurgy A: Mining, 52:1 (2016) 45-56.

[10] M. Mokmeli: Hydrometallurgy, 191 (2020) 105215.

[11] R. Ram, L. Beiza, M. Becker, M. I. Pownceby, M. Chen, Y. Yang, S.Yang J. Petersen: Hydrometallurgy, 192 (2020) 105261.

[12] D. Dreisinger: Hydrometallurgy, 83 (2006) 10-20.

[13] R.G. McDonald, D.M. Muir: Hydrometallurgy, 86 (2007) 191-205.

[14] M. Sokić, B. Marković, S. Stanković, Ž. Kamberović, N. Štrbac, V. Manojlović, N. Petronijević: Metals, 9(11) 2019, 1173.

[15] Y. Ghorbani, M. Becker, A. Mainza, J., Franzidis, J. Petersen: Miner Eng, 24 (2011) 1172-1184

[16] H.R. Watling: Hydrometallurgy, 140 (2013) 163-180.

[17] S. Wang: JOM, 57 (2005) 48-51.

[18] F. K. Crundwell: Hydrometallurgy, 21 (1988) 155-190.

[19] Y. Rodriquez, A. Ballester, M. L. Blazquez, F. González, J. A. Munoz: Hydrometallurgy, 71 (2003) 47-56.

[20] C. de Oliveira, G. F. de Lima, H. A. de Abreu, H. A. Duarte: J Phys Chem C, 116 (10) (2012) 6357-6366.

[21] Y. L. Mikhlin, Y. V. Tomashevich, I. P. Asanov, A. V. Okotrub, V. A. Varnek, D. V. Vyalikh: Appl Surf Sci, 225 (2004) 395-409.

[22] Y. Mikhlin, Y. Tomashevich, V. Tauson, D. Vyalikh, S. Molodtsov, R. Szargan: J Electron Spectrosc Relat Phenom, 142 (2005) 83-88.

[23] F.K. Crundwell: Can Metall Q, 54:3 (2015) 279-288.

[24] G.M. O'Connor, J.J. Eksteen: Miner Eng, 154 (2020) 106401.

[25] J.E. Dutrizac: Metall Trans B, 12B (1981) 371-378.

[26] N.N. Saxena, N.R. Mandre: Hydrometallurgy, 28 (1992) 111-117.

[27] M.M. Antonijevic, G.D. Bogdanovic: Hydrometallurgy, 73 (2004) 245-256. 
[28] Y.J. Xian, S.M. Wen, J.S. Deng, J. Liu, Q. Nie: Can Metall Q, 51 (2012) 133-40.

[29] O.G. Olvera, M. Rebolledo, E. Asselin: Hydrometallurgy, 165 (2016) 148-158.

[30] A.O. Adebayo, K.O. Ipinmorti, O.O. Ajayi: Chem Biochem Eng Q, 17 (2003) 213-218.

[31] M.M. Antonijevic, Z.D. Jankovic, M.D. Dimitrijevic: Hydrometallurgy, 71 (2004) 329-334

[32] S.J. Petrović, G.D. Bogdanović, M.M. Antonijević: Trans Nonferrous Met Soc China, 28 (2018) 1444-1455.

[33] M.J. Nicol: Hydrometallurgy, 193 (2020) 105328

[34] S. Aydogan, G. Ucar, M. Canbazoglu: Hydrometallurgy, 81 (2006) 45-51.

[35] S. Kariuki, C. Moore, A. McDonald: Hydrometallurgy, 96 (2009) 72-76.

[36] N. Hiroyoshi, M. Arai, H. Miki, M. Tsunekawa, T. Hirajima: Hydrometallurgy, 63 (2002) 257-267.

[37] T. Tapera, A.N. Nikoloski: Hydrometallurgy, 183 (2019) 130-141.

[38] F.R. Carillo Pedroza, M.A Sanchez-Castillo, M.J. Soria-Aguilar, A. MartinezLuevanos, E.C. Gutierrez: Can Metall Q, 49 (2010) 219-226.

[39] M. Sokic, B. Markovic, D. Živkovic: Hydrometallurgy, 95 (2009) 273-279.

[40] M. Sokic, V. Matkovic, B. Markovic, N. Štrbac, D. Živkovic: Hem Ind, 64 (2010) 343-350.

[41] M. Al-Harahsheh, S. Kingman, N. Hankins, C. Somerfield, S. Bradshaw, W Louw: Miner Eng, 18 (2005) 1259-1268]

[42] T. Wen, Y. Zhao, Q. Ma, Q. Xiao, T. Zhang, J. Chen, S. Song: J Mater Res Technol, 9:1 (2020) 263-270.

[43] G. Granata, K. Takahashi, T. Kato, C. Tokoro: Miner Eng, 131 (2019) 280-285.

[44] O.J. Solis-Marcíal, G.T. Lapidus: Hydrometallurgy, 131-132 (2013) 120-126.

[45] M.A. Ghomi, M. Mozammel, H. Moghanni, L. Shahka: Hydrometallurgy, 189 (2019) 105120

[46] D. Nava, I. Gonzalez: Electrochim Acta, 51 (2006) 5295-5303.

[47] A. López-Juárez, N. Gutiérrez-Arenas, R.E. Rivera-Santillán: Hydrometallurgy, 83 (2006) 63-68.

[48] M.F.C. Carneirom, V.A. Leao: Hydrometallurgy, 87 (2007) 73-82.

[49] C. Klauber, A. Parker, W. Bronswijk, H. Watling: Int J Miner Process, 62 (2001) 65-94.

[50] E.M. Arce, I. Gonzalez: Int J Miner Process, 67 (2002) 17-28.

[51] J.E. Dutrizac: Can Metall Q, 28:4 (1989) 337-344.

[52] A.J. Parker, R.L. Paul, G.P. Power: J Electroanal Chem, 118 (1981) 305-316.

[53] R.I. Holliday, W.R. Richmond: J Electroanal Chem, 288 (1990) 83-98.

[54] S.L. Harmer, J.E. Thomas, D. Fornasiero, A.G. Gerson: Geochim Cosmochim Acta, 70 (2006) 4392-4402.

[55] C. Klauber: Inter J Miner Process, 86 (2008) 1-17.

[56] P.B. Munoz, J.D., Miller, M.E. Wadsworth: Metall Trans B, 10B (1979) 149-158.

[57] Z.Y. Lu, M.I. Jeffrey, F. Lawson: Hydrometallurgy, 56 (2000) 145-155.

[58] R.P. Hackl, D.B. Dreisinger, E. Peters, J.A. King: Hydrometallurgy, 39 (1995) 25 48.

[59] A. Parker, C. Klauber, A. Kougianos, H.R. Watling, W. Van Bronswijk: Hydrometallurgy, 71 (2003) 265-276.

[60] D.L. Jones, E. Peters, In: Extractive Metallurgy of Copper II, Metall. Soc. AIME. Eds.: Yannopoulos, J.C., Agarwa, J.C. New York 1976, p. 633-653. 
[61] R.S. McMillan, D.J. Mack Kinnon, J.E. Dutrizac: J Appl Electroch, 12 (1982) 743 757.

[62] Q. Yin, G.H. Kelsall, D.J. Vaughan, K.E.R. England: Geochim Cosmochim Acta, 59 (1995) 1091-1100

[63] M.B. Stott, H.R. Watling, P.D. Franzmann, D. Sutton: Miner Eng, 13 (2000) $1117-$ 1127.

[64] D. Buttinelli, R. Lavecchia, F. Pochetti, A. Gaveci, N. Guresin, Y. Topkaya: Int J Miner Process, 36 (1992) 245-257.

[65] J.E. Dutrizac: Metall Trans B, 9B (1978) 431-439.

[66] T. Hirato, M. Majima, Y. Awakura: Metall Trans B, 18B (1987) 489-496.

[67] D. Howard, F.K.A. Crundwell: Process Metall, 9 (1999) 209-217.

[68] K. Kaplun, J. Li, N. Kawashima, A.R. Gerson: Geochim Cosmochim Acta, 75:20 (2011) 5865-5878.

[69] J. Li, N. Kawashima, K. Kaplun, V.J. Absolon, A.R. Gerson: Geochim Cosmochim Acta, 74 (2010) 2881-2893.

[70] G.D. Bogdanović, 2005. Ponašanje minerala halkopirita - luženje i elektrohemijsko tretiranje u rastvorima sumporne kiseline, Doktorska disertacija, Tehnički fakultet u Boru (in Serbian).

[71] N. Hiroyoshi, H. Miki, T. Hirajima, M. Tsunekawa: Hydrometallurgy, 57 (2000) 31-38.

[72] N. Hiroyoshi, S. Kuroiwa, H. Miki, M. Tsunekawa, T. Hirajima: Hyometallurgy, 74 (2004) 103-116.

[73] F. Dakubo, J.C. Baygents, J. Farrell: Hydrometallurgy, 121-124 (2012) 68-73.

[74] V. Mahajan, M. Misra, K. Zhong, M.C. Fuerstenau: Miner Eng, 20 (2007) 670674.

[75] T. Agacayak, A. Aras, S. Aydogan, M. Erdemoglu: Physicochem Probl Miner Process, 50:2 (2014) 657-666.

[76] O.J. Solis-Marcíal, G.T. Lapidus: Hydrometallurgy, 131-132 (2013) 120-126.

[77] M. Antonijevic, Z. Jankovic, M. Dimitrijevic: Hydrometallurgy, 35 (1994) 187201.

[78] G. Ucar, M. Boyrazli, S. Aydogan, In: 7th International Scientific Conference SGEM 2007, p. 44-51.

[79] M. Antonijević: J Serb Chem Soc, 60:3 (1995) 233-240.

[80] P. Canizares, F. Larrondo, J. Lobato, M.A. Rodrigo, C. Saez: J Electrochem Soc, 152 (2005) D191-D196.

[81] J. Lu, D. Dreisinger: Miner Eng, 45 (2013) 185-190.

[82] E.M. Cordoba, J.A. Munoz, M.L Blazquez, F. Gonzalez, A. Ballester: Hydrometallurgy, 93 (2008) 88-96.

[83] S.M.J. Koleini, V. Aghazadeh, A. Sandström: Miner Eng, 24 (2011) 381-386.

[84] C.A.C. Sequeira, D.M.F. Santos, Y. Chen, G. Anastassakis: Hydrometallurgy, 92 (2008) 135-140.

[85] L.E. Murr, J.B. Hiskey: Metall Trans B, 12B (1981) 255-267.

[86] R. Padilla, P. Zambrano, M.C. Ruiz: Metall Mater Trans B, 34B (2003) 153 -159.

[87] H.R. Watling: Hydrometallurgy, 146 (2014) 96-110.

[88] J.E. Dutrizac: Hydrometallurgy, 23 (1990) 153-176.

[89] M. Lundstrom, J. Aromaa, O. Forsen, O. Hyvarinen, M.H. Barker: Hydrometallurgy, 77 (2005) 89-95.

[90] J.P. Wilson, W.W. Fisher: JOM, 33:2 (1981) 52-57.

[91] R. Winand:, 27 (1991) 85 Hydrometallurgy -316. 
[92] [92] F. Habashi, Chalcopyrite-Its Chemistry and Metallurgy, McGraw-Hill, New York, 1978, 142.

[93] M. Al-Harahsheh, S. Kingman, A. Al-Harahsheh: Hydrometallurgy, 91 (2008) 89-97.

[94] T. Hirato, M. Kinoshita, Y. Awakura, H. Majima: Metall Trans B, 17B (1986) 1928.

[95] T. Hirato, H. Majima, Y. Awakura: Metall Trans B, 18B (1987a) 31-39.

[96] B.R. Palmer, C.O. Nebo, M.F. Rau, M.C. Fuerstenau: Metall Mater Trans B, 12B:3 (1981) 595-601.

[97] A.A. Baba, K.I. Ayinla, F.A. Adekola, R.B. Bale, M.K. Ghosh, A.G.F. Alabi, A.R. Sheik, I.O. Folorunso: Int J Miner Metall Mater, 20 (2013) 1021-1027.

[98] L. Velasquez-Yevenes, M. Nicol, H. Miki: Hydrometallurgy, 103 (2010a) 108_113.

[99] L. Velasquez-Yevenes, H. Miki, M. Nicol, Hydrometallurgy, 103 (2010b) 80-85.

[100] R. Padilla, D. Lovera, M.C. Ruiz, In: Proceedings of the EPD Congress, Ed.: Mishra, B., TMS, Warrendale, 1997, pp. 167-177.

[101] M. Skrobian, T. Havlik, M. Ukasik: Hydrometallurgy, 77 (2005) 109-114.

[102] M. Nicol, H. Miki, L. Velásquez-Yévenes: Hydrometallurgy, 103 (2010) 86-95.

[103] N. Hiroyoshi, H. Miki, T. Hirajima, M. Tsunekawa: Hydrometallurgy, 57 (2000) 31-38.

[104] M.D. Turan, M. Boyrazli, H.S. Altundogan: J Cent South Univ, 25 (2018) 21-28.

[105] M. Jafari, G. Karimi, R. Ahmadi: Physicochem Probl Miner Process, 53(2) (2017) 1228-1240.

[106] D.W. Shiers, D.M. Collinson, N.J. Kelly, H.R. Watling: Miner Eng, 85 (2016) 55 65.

[107] D. Ikiz, M. Gülfen, A.O. Aydin:. Miner Eng, 19 (2006) 972-974.

[108] J. Li, N. Kawashima, K. Kaplun, V.J. Absolon, A.R. Gerson: Geochim Cosmochim Acta, 74 (2010) 2881-2893.

[109] M. Dimitrijević, M.M. Antonijević, V. Dimitrijević: Miner Eng, 12 (1999) 165-174.

[110] H.G. Vazarlis: Hydrometallurgy, 19 (1987) 243-251.

[111] A.A. Baba, F.A. Adekola: Int J Miner Metall Mater, 18 (2011) 9-17.

[112] G. He, Z. Zhao, X. Wang, J. Li, X. Chen. L. He, X. Liu: Hydrometallurgy, 144-145 (2014) 140-147.

[113] N.V. Ngoc, M. Shamsuddin, P.M. Prasad, Metall Trans B, 21 (1990) 611-619.

[114] R. Orth, K. Liddell: Ind Eng Chem Res, 29 (1990) 1178-1183.

[115] T. Havlik, M. Skrobian, P. Balaz, R. Kammel: Int J Miner Process, 43 (1995) 61 72.

[116] B.E. Kimball, J.D. Rimstidt, S.L. Brantley: Appl Geochem, 25 (2010) 972-983.

[117] N.K. Jain, J.M. Sharma, D. Kumar: Trans Indian Inst Met, 46:5 (1993) 323-325.

[118] T. Havlik, R. Kammel: Miner Eng, 8 (1995) 1125-1134.

[119] D. Maurice, J.A. Hawk: Hydrometallurgy, 49 (1998) 103-123.

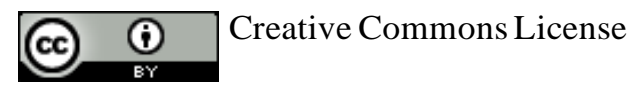

This work is licensed under a Creative Commons Attribution 4.0 International License. 